\title{
Endoscopic Transsphenoidal Approach for Hemangiopericytoma in Sellar Region: A Case Report and Review of the Literature
}

\author{
Pan Wang, Junwei Wang, Dewei Zou, Jinyu Pan, and Nan $\mathrm{Wu}^{*}$ \\ Department of Neurosurgery, Chongqing General Hospital, University of Chinese Academy of Sciences, Chongqing, China
}

*Corresponding author: Nan Wu, Department of Neurosurgery, Chongqing General Hospital, University of the Chinese Academy of Sciences, Jinzhou Avenue, Liangjiang New District, Chongqing 401147, China, Fax: +86 23 63512096; E-mail: wunan881@tmmu.edu.cn

Received: 25 Oct, 2021 | Accepted: 17 Nov, 2021 | Published: 25 Nov, 2021

Citation: Wang P, Wang J, Zou D, Pan J, Wu N (2021) Endoscopic Transsphenoidal Approach for Hemangiopericytoma in Sellar Region: A Case Report and Review of the Literature. J Clin Case Stu 6(6): dx.doi.org/10.16966/2471-4925.242

Copyright: (C) 2021 Wang P, et al. This is an open-access article distributed under the terms of the Creative Commons Attribution License, which permits unrestricted use, distribution, and reproduction in any medium, provided the original author and source are credited.

\section{Abstract}

Background: Hemangiopericytomas (HPCs) with aggressive behavior are rare in the central nervous system and extremely rare in the sellar region. Here we presented a clinical case of HPC in sellar region.

Case presentation: The patient was a 45-year-old man with decreased binocular vision and sexual dysfunction for about one year. The preoperative hormone examination indicated that the anterior pituitary function was decreased. Enhanced magnetic resonance images showed that there were clump like abnormal signals in the sellar region, showing obvious homogeneous enhancement. The mass was totally resected through an endoscopic transsphenoidal approach by adopting the surgical strategy of complete peripheral separation and histopathology revealed HPC, world health organization grade II. After tumor resection, the visual acuity was improved, but the pituitary function was low and appropriate hormones were supplemented.

Conclusion: This is the first report of total resection of HPC in sellar region by complete peripheral separation method, which can reduce bleeding and achieve total resection. Because intracranial HPC appears invasion, recurrence and distant metastasis, total surgical resection is especially necessary. In addition, the preoperative diagnosis of intracranial HPC is relatively difficult. Therefore, the possibility of HPC may be considered when the lesions in sellar region are obviously enhanced and accompanied by anterior pituitary dysfunction.

Keywords: Hemangiopericytoma; Sellar region; Endoscopic transsphenoidal approach; Complete peripheral separation; Case report

\section{Introduction}

Since the epithelioid cells of the glomus tumor are derived from zimmermann pericytes, Stout AP, et al. first proposed the concept of hemangiopericytoma (HPC) to distinguish it from the simple capillary hemangioma in 1942 [1]. HPC is an uncommon tumor with aggressive behavior, which usually appears in limbs, lung, abdominal cavity, pelvic cavity, etc. It rarely appears in the central nervous system. Intracranial HPC is derived from zimmerman pericytes of capillary wall in meningeal stroma, which is spindle cells arranged close to capillary reticular fibrous membrane and a variant smooth muscle cell. The locations of intracanial HPC appears near the dura mater or venous sinus, such as skull base, sagittal sinus or cerebral falx, tentorium of cerebellum, etc. The appearance of intracranial HPC in sellar region is extremely rare, and only 13 cases of sellar HPC have been reported. In this paper, we reported a clinical case of intracranial HPC in sellar region, which is the fourteenth case of sellar HPC and we preformed this surgery through endoscopic transsphenoidal approach. The strategy of transsphenoidal approach was not usually used in sellar HPC previously.

\section{Case Report}

A 45-year-old man with decreased binocular vision and sexual dysfunction for about one year was presented to our hospital on March 13, 2019. He had no history of eye diseases and reproductive system disease during the past. Physical examination showed that the visual acuity of eyes was 0.2 and the diameter of pupils was $2 \mathrm{~mm}$. The endocrine examination is shown in table 1, indicating that anterior pituitary function is significantly decreased. Figure 1 shows preoperative and postoperative enhanced magnetic resonance images (MRI) and endoscopy images during surgery. The preoperative sagittal and axial contrast-enhanced MRI show that there is a mass like abnormal signal in the sellar region, with obvious homogeneous enhancement, which is closely related to the left cavernous sinus, as shown in figures $1 \mathrm{~A}$, and $1 \mathrm{~B}$. Combined with preoperative hormone examination and enhanced MRI, the tumor was initially considered as germ cell tumor. Considering the location of the tumor, the relationship between blood vessels and nerves, and minimizing the trauma, we adopted endoscopic (Karl Storz; Germany) transsphenoidal approach to remove the tumor.

During the operation, the patient was intubated from endotracheal 
Table 1: The endocrine examination of this case.

\begin{tabular}{|c|c|c|c|c|}
\hline \multicolumn{2}{|c|}{ Endocrine Examination } & Reference value & Preoperative value & Postoperative value after 2 months \\
\hline \multirow{6}{*}{ Gonadal axis } & PRL & $2.64-13.13 \mathrm{ng} / \mathrm{ml}$ & $17.11 \mathrm{ng} / \mathrm{ml}$ & $13.60 \mathrm{ng} / \mathrm{ml}$ \\
\hline & FSH & $1.27-19.26 \mathrm{mlU} / \mathrm{ml}$ & $0 \mathrm{mlU} / \mathrm{ml}$ & $4.65 \mathrm{mlU} / \mathrm{ml}$ \\
\hline & $\mathrm{LH}$ & $1.24-8.62 \mathrm{mlU} / \mathrm{ml}$ & $0 \mathrm{mlU} / \mathrm{ml}$ & $1.98 \mathrm{mlU} / \mathrm{ml}$ \\
\hline & E2 & $20-75 \mathrm{pg} / \mathrm{ml}$ & Opg/ml & $3.60 \mathrm{pg} / \mathrm{ml}$ \\
\hline & $\mathrm{T}$ & $1.75-7.81 \mathrm{ng} / \mathrm{ml}$ & Ong/ml & $0.47 \mathrm{ng} / \mathrm{ml}$ \\
\hline & $P$ & $0.1-0.84 \mathrm{ng} / \mathrm{ml}$ & $0.03 \mathrm{ng} / \mathrm{ml}$ & $0.1 \mathrm{ng} / \mathrm{ml}$ \\
\hline \multirow{6}{*}{ Thyroid axis } & T3 & $1.3-3.1 \mathrm{nmol} / \mathrm{l}$ & $1.43 \mathrm{nmol} / \mathrm{l}$ & $1.63 \mathrm{nmol} / \mathrm{l}$ \\
\hline & $\mathrm{T} 4$ & $66-181 \mathrm{nmol} / \mathrm{l}$ & $50.55 \mathrm{nmol} / \mathrm{l}$ & $105.60 \mathrm{nmol} / \mathrm{l}$ \\
\hline & FT3 & 3.1-6.8pmol/l & $3.33 \mathrm{pmol} / \mathrm{l}$ & $4.17 \mathrm{pmol} / \mathrm{l}$ \\
\hline & FT4 & $12-22 \mathrm{pmol} / \mathrm{l}$ & $6.45 \mathrm{pmol} / \mathrm{l}$ & $13.91 \mathrm{pmol} / \mathrm{l}$ \\
\hline & $\mathrm{TSH}$ & $0.27-4.20 \mathrm{ulU} / \mathrm{ml}$ & $0.476 \mathrm{ulU} / \mathrm{ml}$ & $0.162 \mathrm{ulU} / \mathrm{ml}$ \\
\hline & $\mathrm{GH}$ & $0.55-4.74 \mathrm{ng} / \mathrm{ml}$ & $0.07 \mathrm{ng} / \mathrm{ml}$ & $0.17 \mathrm{ng} / \mathrm{ml}$ \\
\hline \multirow{2}{*}{ Adrenal axis } & COR & $181.86-716.3 \mathrm{nmol} / \mathrm{l}$ & $33.04 \mathrm{nmol} / \mathrm{l}$ & $266.69 \mathrm{nmol} / \mathrm{l}$ \\
\hline & АCTH & $5-60 \mathrm{pg} / \mathrm{ml}$ & $3.53 \mathrm{pg} / \mathrm{ml}$ & $7.16 \mathrm{pg} / \mathrm{ml}$ \\
\hline
\end{tabular}

PRL: Prolactin; FSH: Follicle Stimulating Hormone; LH: Luteinizing Hormone; E2: Estradiol; T: Testosterone; P: Progesterone; T3: Triiodothyronine; T4: Thyroxine; FT3: Free Triiodothyronine; FT4: Free Thyroxine; TSH: Thyroid-Stimulating Hormone; GH: Growth Hormone; COR: Cortisol; ACTH: Adrenocorticotropic Hormone.
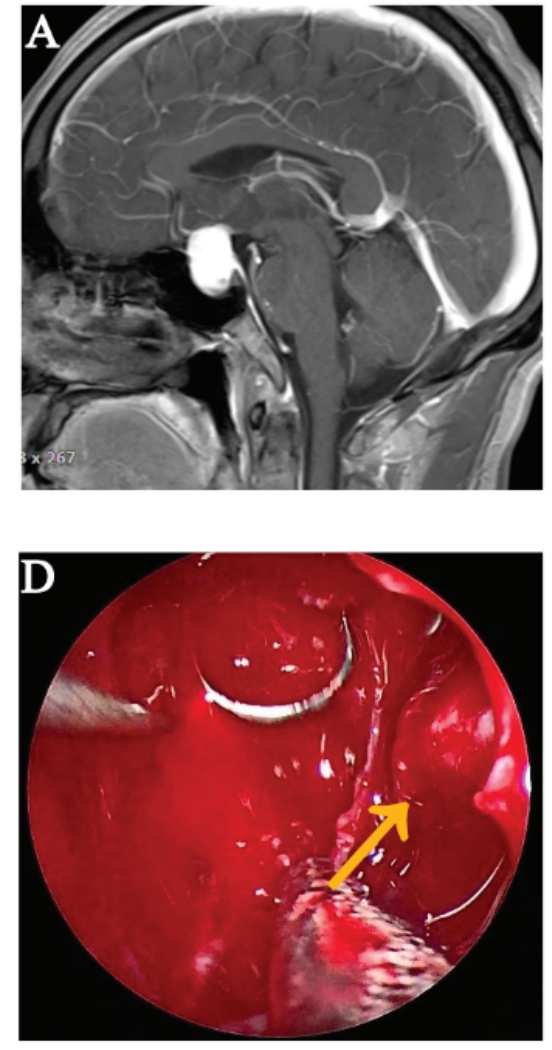

Figure 1: Preoperative and postoperative MRI and endoscopy images during surgery. A). Preoperative sagittal contrast-enhanced MRI showing the tumor in the sellar region. B). Preoperative axial contrast-enhanced MRI showing the tumor in the sellar region, invading the left cavernous sinus. C). Intraoperative view of the tumor (arrow direction). D). endoscopy images showing the left cavernous sinus (arrow direction) after complete resection. E and F). Postoperative MRI showing complete tumor resection.
Citation: Wang P, Wang J, Zou D, Pan J, Wu N (2021) Endoscopic Transsphenoidal Approach for Hemangiopericytoma in Sellar Region: A Case Report and Review of the Literature. J Clin Case Stu 6(6): dx.doi.org/10.16966/2471-4925.242 
intubation, general anesthesia, supine position. According to the preoperative MRI, the left nostril endoscopic transsphenoidal approach was selected to remove the tumor. Under the guidance of endoscopy, the opening diameter in sphenoid sinus was about $1 \mathrm{~cm}$ through the middle turbinate and septum, the septum of the sphenoid sinus was removed, the opening diameter in the sellar floor was about $2 \mathrm{~cm}$. After cutting the dura, we can see the tumor shown in figure $1 \mathrm{C}$ (arrow direction), which was yellow white, brittle, rich in blood supply, clear boundary, and obvious adhesion with the left cavernous sinus. Due to uncertainty of tumor type, the biopsy was taken and sent for freezing, indicating pituitary tumor. Generally, pituitary adenomas are considered to originate from tumors of anterior pituitary gland, most of which are benign tumors and grow slowly. For the treatment of this kind of tumor, sometimes the tumor cannot be completely resected to protect pituitary function, and it will not affect the prognosis. However, there are some features of pituitary adenoma not consistent with this tumor, which arouses our high vigilance. Considering the possibility of other malignant tumors, the tumor was totally resected by adopting a complete peripheral separation strategy, which can be proved by the images during surgery and postoperative MRI shown in figures $1 \mathrm{D}, 1 \mathrm{E}$, and $1 \mathrm{~F}$. After tumor resection, the pituitary gland was located on the left side and no residual tumor was found in the sellar region. Moreover, the tumor near the left cavernous sinus was also totally removed and the left cavernous sinus was clearly visible and shown as figure 1D (arrow direction). Finally, the remaining space was filled with gelatin sponge, and multilayer artificial dura were used to repair the sellar floor and prevent cerebrospinal fluid leakage. After tumor resection, the visual acuity was improved, while the pituitary hormones were relatively low and supplemented. After 2 months, endocrine examination showed that hormones increased and sexual function partially recovered.

To further clarify the diagnosis, the tumor tissues were examined by microscopy and immunohistochemistry. According to hematoxylin and eosin stain in figure $2 \mathrm{~A}$, the tumor cells were oval and arranged around the dilated thin-walled blood vessels. The results of immunohistochemistry indicated that tumor tissue were positive for Bcl-2 (Figure 2B), CD99 (Figure 2C), CD34 (Figure 2D), STAT-6 (Figure 2E), S-100 (Figure 2F), and vimentin (Figure 2G), while tumor tissue presented negative reaction to EMA, CK, CgA, Syn, GFAP, and TTF1. Ki-67 value reached $8 \%$. The above pathological results features met the diagnosis for HPC, world health organization (WHO) grade II, with reference to WHO 2016 [2]. Postoperative radiotherapy was accepted and there was no recurrence after 29 months.

\section{Discussion}

HPC is common in the body's soft tissue and rare in the central nervous system, accounting for less than $1 \%$ of all primary intracranial tumors [3]. In 1954, Begg and Garret reported the first case of primary intracranial HPC in the central left parietal area [4]. Jääskeläinen J, et al. summarized 21 cases with intracranial HPC treated between 1953 and 1983 in Helsinki University Central Hospital [5]. The specific locations of these tumors were in the following regions: parasagittal frontal ( 1 case), parasagittal parietal ( 2 cases), parasagittal occipital (4 cases), falcial frontal (2 cases), falcial parietal (3 cases), falcial occipital ( 2 cases), tentorial occipital ( 3 cases), olfactory ( 1 case), middle fossa ( 2 cases), and pontine angle ( 1 case) [5]. Meanwhile, 44 cases and 17 cases of intracranial HPC were reported in the mayo clinic (1938 1987) and Hospital de la Timone Adultes (1965 1999), respectively, including 3 cases in sellar and super sellar [6,7]. Fountas KN, et al. reported 11 cases of intracranial HPC from 1993 to 2003, and there was no case in sellar region [8]. Wu W, et al. presented 23 cases of intracranial HPC treated in Jinling Hospital (1984 2005), of which 3 cases were in sellar and suprasellar [9]. Zeng LC, et al. presented 58 cases of intracranial HPC treated in Tongji Hospital, Guanggu Hospital, and Caidian Hospital (2002 2012), including only one case in sellar [10]. Recently, Yamaki VN, et al. showed several cases about intracranial HPC, such as a 31-year-old male with a left parieto-occipital extraaxial HPC, a 62-year-old female with a left frontoparietal parafalcine HPC, a 57-year-old male with a right frontal on the convexity HPC [11]. In addition, there were some cases of intracranial HPC occurring in the third ventricle, the body of the lateral ventricle, the frontal horn of the lateral ventricle, the fourth ventricle, etc. [12-15]. Based on the above literature, it can be seen that intracranial HPC in sellar region is particularly rare.

Through literature search for keywords of "hemangiopericytoma" and "sellar", we found 13 detailed cases of HPC in sellar region shown in table 2. The details of these cases, including the patient's gender and age, tumor location and size, surgical approach, tumor resection, follow-up, etc. are shown in table 2. Including our case, there were 6 females and 8 males. The patient's age at diagnosis ranged from 18 to 69 , with an average age of 42 and a median age of 44 . The average/median age of female and male were about $46 / 47$ and 40/44, respectively. In these cases, sellar HPC often involved cavernous sinus and sphenoid sinus, and some also presented the characteristics of compressing optic nerve and ventricle. Hence, the common clinical symptoms presented headache, decreased vision, etc. The maximum HPC size of these cases
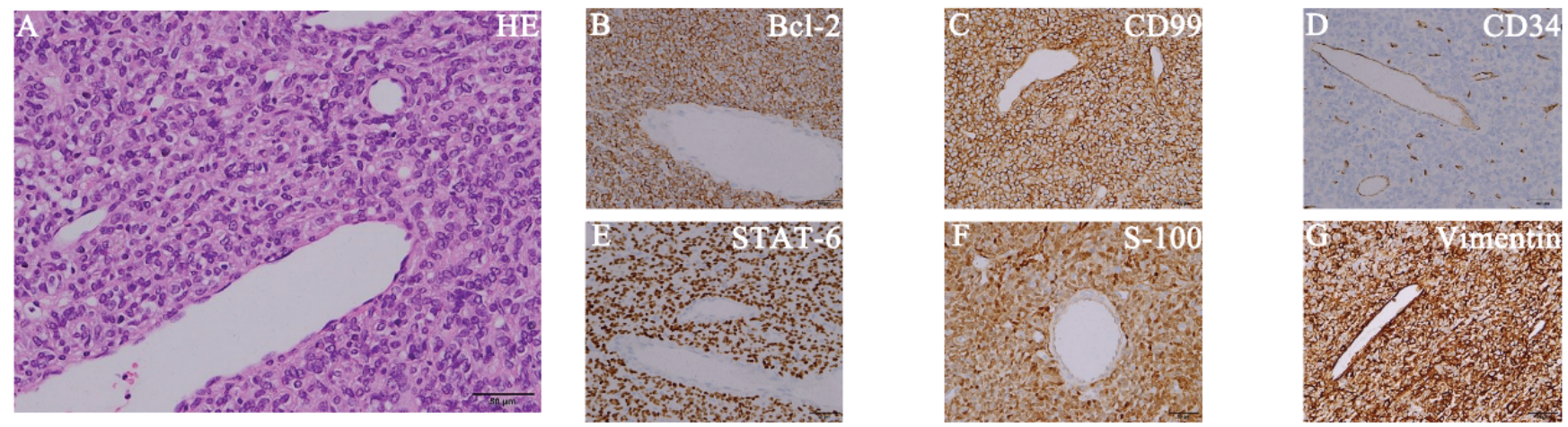

Figure 2: Portable chest radiograph demonstrating a left-sided tension pneumothorax, with mediastinal shift and consolidation throughout the right lung.

Citation: Wang P, Wang J, Zou D, Pan J, Wu N (2021) Endoscopic Transsphenoidal Approach for Hemangiopericytoma in Sellar Region: A Case Report and Review of the Literature. J Clin Case Stu 6(6): dx.doi.org/10.16966/2471-4925.242 
Table 2: HPC in the sellar region from all the references.

\begin{tabular}{|c|c|c|c|c|c|c|c|}
\hline No. & Age/Sex & Location/Size & Approach of surgery & $\begin{array}{c}\text { Tumor } \\
\text { characteristics }\end{array}$ & $\begin{array}{l}\text { Degree of } \\
\text { resection }\end{array}$ & Follow-up & Reference \\
\hline 1 & $59 / F$ & $\begin{array}{c}\text { Sellar, suprasellar } \\
\text { and sphenoid sinus } \\
\text { extension/- }\end{array}$ & Transsphenoidal & $\begin{array}{l}\text { Firm, granular, } \\
\text { yellow-white }\end{array}$ & Totally & - & $\begin{array}{l}\text { Mangiardi JR, et } \\
\text { al. } 1983 \text { [16] }\end{array}$ \\
\hline 2 & $35 / F$ & $\begin{array}{l}\text { Suprasellar, } \\
\text { copressing the } \\
\text { third ventricle/- }\end{array}$ & Craniotomy & Reddish-brown & Totally & - & $\begin{array}{l}\text { Yokota M, et al. } \\
1985 \text { [17] }\end{array}$ \\
\hline 3 & $18 / \mathrm{M}$ & $\begin{array}{l}\text { Sellar, suprasellar } \\
\text { and parasellar } \\
\text { extension/- }\end{array}$ & $\begin{array}{c}\text { Craniotomy+craniotomy* } \\
\text { +craniotomy*+transsphenoidal* }\end{array}$ & - & Partially+totally & $\begin{array}{c}\text { Recurrence after about } \\
3 \text { years+radiotherapy }\end{array}$ & $\begin{array}{l}\text { Kumar PP, et al. } \\
1987[18] \\
\text { Kumar PP, et al. } \\
1988 \text { [19] }\end{array}$ \\
\hline 4 & $35 / F$ & $\begin{array}{l}\text { Sellar, suprasellar } \\
\text { extension/- }\end{array}$ & Transsphenoidal & $\begin{array}{l}\text { Soft, pale, } \\
\text { vascular, } \\
\text { bleeding }\end{array}$ & - & $\begin{array}{c}\text { Radiotherapy+residual } \\
\text { tumor after } 1 \text { year }\end{array}$ & $\begin{array}{l}\text { Morrison DA, et } \\
\text { al. } 1997 \text { [20] }\end{array}$ \\
\hline 5 & $44 / \mathrm{M}$ & $\begin{array}{c}\text { Sellar, parasellar } \\
\text { and sphenoid sinus } \\
\text { extension /- }\end{array}$ & - & - & - & $\begin{array}{l}\text { Spontaneous necrosis of } \\
\text { tumor after } 6 \text { months }\end{array}$ & $\begin{array}{l}\text { Gharbi A, et al. } \\
\qquad 2001[21]\end{array}$ \\
\hline 6 & $60 / \mathrm{F}$ & Sellar/- & Transsphenoidal + craniotomy & - & No** + partially & $\begin{array}{l}\text { Radiotherapy + no } \\
\text { recurrence after } 20 \\
\text { months }\end{array}$ & $\begin{array}{l}\text { Kanda Y, et al. } \\
2001[22]\end{array}$ \\
\hline 7 & $44 / M$ & $\begin{array}{l}\text { Sellar, suprasellar } \\
\text { extension } / 3.0 \times 2.5 \\
\quad \times 4.0 \mathrm{~cm} /-\end{array}$ & Craniotomy & $\begin{array}{l}\text { Highly } \\
\text { vasaularized }\end{array}$ & Subtotally & $\begin{array}{c}\text { Radiotherapy }+ \\
\text { recurrence after } 9 \text { years }\end{array}$ & $\begin{array}{c}\text { Han MH, et al. } \\
2007[23]\end{array}$ \\
\hline 8 & $18 / \mathrm{F}$ & $\begin{array}{l}\text { Sellar, suprasellar } \\
\text { extension/- }\end{array}$ & Transsphenoidal & $\begin{array}{l}\text { Dense, rubbery, } \\
\text { highly vascular, } \\
\text { gray semisolid }\end{array}$ & Totally & $\begin{array}{l}\text { Radiotherapy + no } \\
\text { recurrence after } 27 \\
\text { months }\end{array}$ & $\begin{array}{c}\text { Juco J, et al. } 2007 \\
{[24]}\end{array}$ \\
\hline 9 & $35 / M$ & $\begin{array}{l}\text { Sellar, suprasellar } \\
\text { extension/- }\end{array}$ & Craniotomy + craniotomy* & $\begin{array}{c}\text { Fleshy, elastic } \\
\text { in consistency, } \\
\text { not suckable, } \\
\text { vascular }\end{array}$ & $\begin{array}{l}\text { Totally + } \\
\text { subtotally }\end{array}$ & $\begin{array}{l}\text { Radiotherapy + no } \\
\text { recurrence after } 6 \\
\text { months }\end{array}$ & $\begin{array}{l}\text { Jalali R, et al. } \\
2008[25]\end{array}$ \\
\hline 10 & $47 / M$ & $\begin{array}{l}\text { Sellar, and } \\
\text { suprasellar and } \\
\text { sphenoid sinus } \\
\text { extension } / 3.0 \times \\
2.5 \times 2.2 \mathrm{~cm}\end{array}$ & Transsphenoidal & $\begin{array}{l}\text { Brownish gray, } \\
\text { moderately } \\
\text { vascular, } \\
\text { suckable }\end{array}$ & Subtotally & $\begin{array}{l}\text { Radiotherapy + no } \\
\text { recurrence }\end{array}$ & $\begin{array}{l}\text { Das P, et al. } 2010 \\
{[26]}\end{array}$ \\
\hline 11 & $51 / \mathrm{M}$ & $\begin{array}{l}\text { Sellar, suprasellar } \\
\text { and parasellar } \\
\text { extension } / 3.0 \times \\
2.3 \times 2.0 \mathrm{~cm}\end{array}$ & $\begin{array}{l}\text { Transsphenoidal + } \\
\text { craniotomy*** }\end{array}$ & $\begin{array}{l}\text { Markedly } \\
\text { vascular, soft, } \\
\text { red }\end{array}$ & $\begin{array}{l}\text { Subtotally + } \\
\text { totally }\end{array}$ & - & $\begin{array}{c}\text { Esquenazi Y, et al. } \\
2014 \text { [27] }\end{array}$ \\
\hline 12 & $34 / M$ & $\begin{array}{l}\text { Sellar, suprasellar } \\
\text { extension } / 3.7 \times 3.5 \\
\times 2.2 \mathrm{~cm}\end{array}$ & Craniotomy* & - & Subtotally & $\begin{array}{l}\text { Radiosurgery }+ \text { died } \\
\text { after } 7 \text { months }\end{array}$ & $\begin{array}{c}\text { Gibson B, et al. } \\
2017 \text { [28] }\end{array}$ \\
\hline 13 & $69 / F$ & $\begin{array}{c}\text { Sellar, and } \\
\text { suprasellar } \\
\text { extension } / 2.1 \times 1.2 \\
\times 2.4 \mathrm{~cm}\end{array}$ & Craniotomy & - & Totally & No recurrence & $\begin{array}{c}\text { Gunasekaran A, et } \\
\text { al. } 2020 \text { [29] }\end{array}$ \\
\hline 14 & $45 / M$ & $\begin{array}{c}\text { Sellar, and } \\
\text { parasellar } \\
\text { extension } / 2.7 \times 2.0 \\
\times 1.5 \mathrm{~cm}\end{array}$ & Transsphenoidal & $\begin{array}{l}\text { Yellow white, } \\
\text { brittle, rich in } \\
\text { blood supply }\end{array}$ & Totally & $\begin{array}{l}\text { Radiosurgery + no } \\
\text { recurrence after about } \\
29 \text { months }\end{array}$ & Present case \\
\hline
\end{tabular}

M: Male; F: Female; *: Recurrence; ${ }^{* *}$ : The tumor was not removed due to bleeding; ***: Residual tumor. 
was about $3.7 \times 3.5 \times 2.2 \mathrm{~cm}$, which does not belong to huge tumors in the sellar region. However, due to the abundant blood supply of HPC and excessive bleeding during resection, which increases the difficulty of total resection. In some cases, because of the obvious bleeding during the operation, the HPC can only be partially removed, or the HPC can be totally resected by a series of surgeries. Hence, how to achieve total resection of HPC is also an enormous challenge. One of these cases, due to excessive bleeding, a patient's first transsphenoidal surgery was suspended without resecting the tumor, and then the tumor was resected through the second craniotomy. One case underwent the first transsphenoidal surgery to resect part of tumor, and recurrence after 3 years, then again underwent three craniotomy operations. In our case, the tumor was segmented initially and there was much bleeding. To reduce bleeding, we adopted a surgical strategy of complete peripheral separation and achieved tumor total resection. In table 2, the followup of three cases was not presented, and one case showed spontaneous tumor necrosis. Excluding these four cases, $80 \%$ of cases received postoperative radiotherapy and the recurrent cases is as high as $40 \%$. The latest recurrence time was 9 years, the shortest recurrence time was 3 months (due to second recurrence), and the average recurrence time was about 3.3 years. In our case, postoperative radiotherapy was also accepted and there was no recurrence after 29 months. Due to the malignant invasiveness and high recurrence rate of HPC, we suggest that total surgical resection combined with postoperative radiotherapy may be an effective treatment strategy.

\section{Conclusion}

Intracranial HPC in sellar region is rare and usually aggressive. Here we reported a 45-year old man with HPC in sellar region, which is the fourteenth case of sellar HPC. Through endoscopic transsphenoidal surgery and postoperative radiotherapy, the tumor was totally resected and there was no recurrence after 29 months. Based on this case, we put forward some suggestions for the treatment of HPC. Firstly, preoperative diagnosis of intracranial HPC is relatively difficult, because the MRI of HPC, meningioma and pituitary tumor are similar [30]. In addition, it is also difficult to different HPC and cavernous sinus cavernous hemangioma before surgery, but we can identify it during the surgery, as cavernous sinus cavernous hemangioma is located in cavernous sinus, while HPC stay out of the cavernous sinus. Preoperative predisposition diagnosis is very important and affects the surgical strategy. Secondly, HPC has abundant blood supply and serious bleeding during surgery, which brings great difficulties to surgical resection. For massive bleeding during surgery, we propose a surgical strategy of complete peripheral separation, which can significantly reduce bleeding and is conducive to total resection. Finally, considering the aggressive nature of HPC, postoperative radiotherapy is necessary. Therefore, the complete peripheral separation method is a good way for total resection, and postoperative adjuvant radiotherapy is also important to improve the prognosis of HPC.

\section{Acknowledgements}

Not applicable.

\section{Funding}

The work is funded by science foundation of Chongqing general hospital (CGHZDXM-001).

\section{Availability of Data and Materials}

The datasets in the present study are available from the corresponding author upon reasonable request.

\section{Author's Contributions}

Wang $\mathrm{P}$ and $\mathrm{Wu} \mathrm{N}$ examined the patient, did the surgery and wrote the manuscript. Wang JW helped to finish the surgery. Zou DW collected the data. Pan JY examined the patient and helped to collect the data of the patient. All authors approved the final manuscript.

\section{Ethics Approval and Consent to Participate}

The study was conducted ethically in accordance with the World Medical Association's Declaration of Helsinki.

\section{Patient Consent for Publication}

Written informed consent for publication of the present report was obtained from the patient.

\section{Declaration of Conflicting Interest}

The authors declare that there is no conflict of interest.

\section{References}

1. Stout AP, Murray MR (1942) Hemangiopericytoma: A Vascular Tumor Featuring Zimmermann's Pericytes. Ann Surg 116: 26-33.

2. Louis DN, Perry A, Reifenberger G, von Deimling A, Figarella-Branger D, et al. (2016) The 2016 World Health Organization Classification of Tumors of the Central Nervous System: a summary. Acta Neuropathol 131: 803-820.

3. Bai LC, Luo TY, Zhu H, Xu R (2017) MRI features of intracranial anaplastic hemangiopericytoma. Oncol Lett 13: 2945-2948.

4. Begg CF, Garret R (1954) Hemangiopericytoma occurring in the meninges: case report. Cancer 7: 602-606.

5. Jääskeläinen J, Servo A, Haltia M, Wahlström T, Valtonen S (1985) Intracranial hemangiopericytoma: radiology, surgery, radiotherapy, and outcome in 21 patients. Surg Neurol 23: 227-36.

6. Guthrie BL, Ebersold MJ, Scheithauer BW, Shaw EG (1989) Meningeal hemangiopericytoma: histopathological features, treatment, and long-term follow-up of 44 cases. Neurosurgery 25: 514-522.

7. Dufour H, Métellus P, Fuentes S, Murracciole X, Régis J, et al. (2001) Meningeal hemangiopericytoma: a retrospective study of 21 patients with special review of postoperative external radiotherapy. Neurosurgery 48: 756-762.

8. Fountas KN, Kapsalaki E, Kassam M, Feltes $\mathrm{CH}$, Dimopoulos $V G$, et al. (2006) Management of intracranial meningeal hemangiopericytomas: outcome and experience. Neurosurg Rev 29: $145-153$.

9. Wu W, Shi JX, Cheng HL, Wang HD, Hang $\mathrm{CH}$, et al. (2009) Hemangiopericytomas in the central nervous system. J Clin Neurosci 16: 519-523.

10. Zeng L, Wang $Y$, Wang $Y$, Han L, Niu HQ, et al. (2017) Analyses of prognosis-related factors of intracranial solitary fibrous tumors and hemangiopericytomas help understand the relationship between the two sorts of tumors. J Neurooncol 131: 153-161.

11. Yamaki VN, de Souza Godoy LF, Bandeira GA, Lucato LT, Lordelo GC, et al. (2021) Dural-based lesions: is it a meningioma? Neuroradiology 63: 1215-1225.

12. Abrahams JM, Forman MS, Lavi E, Goldberg H, Flamm ES (1999) Hemangiopericytoma of the third ventricle. Case report. J Neurosurg 90: 359-362. 
13. Sumi K, Watanabe T, Ohta T, Fukushima T, Kano T, et al. (2010) Hemangiopericytoma arising in the body of the lateral ventricle. Acta Neurochir (Wien) 152: 145-149.

14. Avinash KS, Thakar S, Ghosal N, Hegde AS (2016) Anaplastic hemangiopericytoma in the frontal horn of the lateral ventricle. J Clin Neurosci 26: 147-149.

15. Yang $H$, Zhang $Y$, Zheng $T$, Li C, Tang G, et al. (2019) A solitary fibrous tumor/hemangiopericytoma of the fourth ventricle: case report and literature review. J Int Med Res 47: 6349-6355.

16. Mangiardi JR, Flamm ES, Cravioto H, Fisher B (1983) Hemangiopericytoma of the pituitary fossa: case report. Neurosurgery 13: 58-62.

17. Yokota M, Tani E, Maeda $Y$, Morimura T, Kakudo $K$, et al. (1985) Acromegaly associated with suprasellar and pulmonary hemangiopericytomas. Case report. J Neurosurg 62: 767-771.

18. Kumar PP, Good RR, Skultety FM, Masih AS, McComb RD (1987) Spinal metastases from pituitary hemangiopericytic meningioma. Am J Clin Oncol 10: 422-428.

19. Kumar PP, Good RR, Leibrock LG, Mawk JR, Yonkers AJ, et al. (1988) High activity iodine 125 endocurietherapy for recurrent skull base tumors. Cancer 61: 1518-1527.

20. Morrison DA, Bibby K (1997) Sellar and suprasellar hemangiopericytoma mimicking pituitary adenoma. Arch Ophthalmol 115: 1201-1203.

21. Gharbi A, Ousehal A, Kissani N, Lakhdar A, Azhari A, et al. (2001) Sellar hemangiopericytoma-Report of a case. J Neuroradiol 28: 195199.

22. Kanda Y, Mase M, Aihara N, Yamada K, Sugino F, et al. (2001) Sellar hemangiopericytoma mimicking pituitary adenoma. Surg Neurol 55 113-115.
23. Han MH, Cho YD, Kim YD, Kim DH (2007) Recurrent sellar and suprasellar hemangiopericytoma. J Korean Neurosurg Soc 41: 425428.

24. Juco J, Horvath E, Smyth H, Rotondo F, Kovacs K (2007) Hemangiopericytoma of the sella mimicking pituitary adenoma: case report and review of the literature. Clin Neuropathol 26: 288293

25. Jalali R, Srinivas C, Nadkarni TD, Rajasekharan P (2008) Suprasellar haemangiopericytoma--challenges in diagnosis and treatment. Acta Neurochir (Wien) 150: 67-71.

26. Das P, Haresh KP, Suri V, Sharma MC, Sharma BS, et al. (2010) Malignant hemangiopericytoma of pituitary fossa. Indian J Pathol Microbiol 53: 109-111.

27. Esquenazi Y, Shank C, Tandon N, Bhattacharjee M (2014) Lipomatous hemangiopericytoma of the sellar region: case report and review of the literature. Ann Clin Lab Sci 44: 104-108.

28. Gibson B, Mancini C, Parker J, Applebaum M, Alatassi H (2017) Sellar and Suprasellar Anaplastic Hemangiopericytoma in a 34-Year Old Man. Ann Clin Lab Sci 47: 349-353.

29. Gunasekaran A, Santos JM, Vandergrift WA $3^{\text {rd }}$ (2020) Supraorbital Craniotomy for Sellar Solitary Fibrous Tumor: Operative Technique and Literature Review. World Neurosurg 141: 395-401.

30. Ma C, Xu F, Xiao YD, Paudel R, Sun Y, et al. (2014) Magnetic resonance imaging of intracranial hemangiopericytoma and correlation with pathological findings. Oncol Lett 8: 2140-2144. 